\title{
Species Composition and Habitat Preference of Rotifera in Ahansar Lake
}

\author{
${ }^{1}$ Irfan , J , ${ }^{2}$ Yousuf , A .R, ${ }^{3}$ Parveen .M \\ ${ }^{1,2,3}$ Department Of Centre of Research For Development University Of Kashmir
}

\begin{abstract}
During the course of an extensive study of the ecology and systematics of the rotifera from Ahansar lake, 26 species of rotifer belonging to 14 genera, 9 families were recorded for the first time. An analysis of the family wise representation of the recorded species depicted the relative qualitative sequence to be Brachionidae $>$ Trichocercidae $=$ Lecanidae . Brachionidae comprised $65 \%$ of the overall species richness . Shannon's diversity index showed highest species richness at macrophyte infested littoral zone and maximum diversity was recorded in Summer .
\end{abstract}

Key Words: Rotifers, Species richness, Littoral zone

\section{Introduction}

Rotifers are among the groups of zooplankton with the largest populations in continental waters, frequently dominating the fauna. They are considered to be cosmopolitan in nature .Globally around 2000 species of rotifers are known (Shiel , 1995 ). They are usually restricted into a littoral zone due to favourable light conditions ( Mikulski , 1974 ). The occurrence and number of rotifers are often modified by the habitat preference of a species which is connected with overall food conditions which occur within a particular water body ( De Azavedo and Bonecker , 2003 ). The littoral region is often the most diverse part of the lake community, supporting variety of macrophytes, their associate microflora and large number of animal species . Diversity is often high in the vegetative habitats as compared with pelagic ( Pennak, 1966). Representatives of rotifers are found in aquatic and semi aquatic habitats, but are predominantly fresh water inhabitants ( Pejler , 1995 ). They contribute to a a very important part of these ecosystems due to extremely fast reproductive rates

Rotifera an integral and important component of aquatic food webs have been documented from a wide variety of fresh water bodies of Kashmir . But there is currently limited information on their diversity in flood plain lakes of Kashmir as many of the lakes have been neglected, Ahansar lake is one of them . The aim of present work was to study species composition of Rotifera and their habitat preferences in Ahansar lake .

\section{Study Area And Study Sites}

The present study is a part of limnological survey undertaken during December 2011 to October 2012 in Ahansar lake .Ahansar lake is a small fresh water rural lake situated at Sumbal ( District , Ganderbal ),26 $\mathrm{Km}$ north of Srinagar . It lies between $34^{0} 13^{\prime} 43.5^{\prime \prime} \mathrm{N}$ Latitude $74^{0} 39^{\prime} \cdot 49.4^{\prime \prime}$ E Longitude at an elevation of $1594 \mathrm{~m}($ a.s.l).

He lake has a maximum depth of $5 \mathrm{~m}$ and is spread over an area of $0.8 \mathrm{Km}$ square. The lake is fed by many springs. The lake supports luxuriant growth of macrophytes which form continuous belt along the periphery of the lake. Few studies have been undertaken on this lake. The present study is the first survey of Rotifera from Ahansar lake. In present day research TBiodiversity is achieving a tremendous importance where collection of base line data related to flora and fauna is important . If such studies are not carried out many of the organisms may go unrecorded. Hence it is very important to put into record the studies of organisms .

\section{Two study sites were selected from the lake .}

SITE 1 : - It is located in the littoral zone with dense tall emergents towards the north side . SITE 2: -It is located in the open water zone towards the east side.

\section{Materials And Methods}

For qualitative analysis collection of the plankton was carried out by hauling plankton net fitted with nylobolt net cloth no . 140T through water in vertical and horizontal directions. The contents collected in the tube attached to the lower end of the net were transferred to separate marked polythene tubes and preserved in $4 \%$ formalin. Detailed qualitative investigations were made under compound microscope and different taxa identified with the help of standard taxonomic works like Edmondson ( 1959 ), Pennak ( 1978 ).For quantitative enumeration 100 litres of water was sieved through the plankton net and preserved in $4 \%$ formalin. The samples were reduced or concentrated to known volume of $10 \mathrm{ml}$ in a centrifuge for about $10-15$ minutes at $1500 \mathrm{rpm}$. The quantitative enumeration of the individuals was done by counting $1 \mathrm{ml}$ aliquot of the centrifuged sub sample 
in a Sedgwick rafter cell ( $1 \mathrm{ml}$ capacity ) under a binocular microscope .For accuracy same volume of the sub sample were counted $3-5$ times and average of the values was taken for calculating the number of organisms per cubic meter of the water by the formula given in APHA ( 1998 ). The results were expressed in indi /1 .

Diversity index $\hat{H}$ (Shannon and Weaver, 1949) was applied to define the species diversity of rotifers inhabiting two zones.

$\hat{\mathrm{H}}=-\sum \frac{n i}{N} \times \ln \frac{n i}{N} \quad$ Where $\hat{\mathrm{H}}=$ Shannon - weaver index

$\mathrm{ni}=$ The number of individuals of its species

$\mathrm{N}=$ The total no. of individuals

\section{Result And Discussion}

In the present investigation 26 different Rotifer taxa from 3 orders Ploima, Flosculariaceae and Philodinidae belonging to 14 genera and 8 families were recorded from two sampling sites in Ahansar Lake. Out of these 24 species, 12 genera and 6 families belonged to order Ploima.

Brachionidae was the dominant family.According to Sharma and Michael (1980) Brachionidae form significant fraction of total Rotifera and form an important component of plankton. In the

present study Brachionidae was represented by 15 species( $65 \%$ ). Trichocercidae (13\%), Lecanidae(13\%) form notable fraction of rotifer at Ahansar lake. Notammatidae, Gastropodidae and Synchaetidae also showed some importance with only one species each ( see Systematic list and fig 1 ).

Systematic list of Rotifers from Ahansar lake

\begin{tabular}{|c|c|}
\hline ORDER & PLOIMA \\
\hline (A) Family & Brachionidae \\
\hline 1. Genus & Brachionus \\
\hline \multirow[t]{5}{*}{ Species } & Brachionus angularis Gossi 1851 \\
\hline & Brachionus bidentata Anderson, 1889 \\
\hline & Brachionus calyciflorus Pallas, 1766 \\
\hline & Brachionus plicatalis Muller, 1786 \\
\hline & Brachionus quadridentata $\quad$ Hermann 1783 \\
\hline 2.Genus & Keratella \\
\hline \multirow[t]{3}{*}{ Species } & Keratella cochlearis Gosse, 1851 \\
\hline & Keratella haemalis Carlin , 1943 \\
\hline & Keratella quadrata Muller, 1786 \\
\hline 3. Genus & Mytilina \\
\hline Species & Mytilina mucronata Muller, 1773 \\
\hline 4.Genus & Notholca \\
\hline Species & Notholca acuminate Gosse , 1887 \\
\hline 5. Genus & Platiyas \\
\hline \multirow[t]{2}{*}{ Species } & Platiyas patulus O.F .Muller, 1786 \\
\hline & $\begin{array}{l}\text { Platiyas quadricornis Ehrenberg, } \mathbf{1 8 3 2} \\
\end{array}$ \\
\hline 6. Genus & Trichotria \\
\hline Species & Trichotria tetractris Ehrenberg, 1830 \\
\hline 7. Genus & Lepadella \\
\hline \multirow[t]{2}{*}{ Species } & Lepadella O . F .Muller, 1786 \\
\hline & Lepadella patella O . F .M uller, 1773 \\
\hline (B) .Family & Lecanidae \\
\hline 8. Genus & Monostyla \\
\hline \multirow[t]{3}{*}{ Species } & Monostyla bulla Gosse, 1851 \\
\hline & Monostyla lunaris Ehrenberg, 1832 \\
\hline & Monostyla quadridentata Ehrenberg, 1830 \\
\hline ( C). Family & Notommatidae \\
\hline
\end{tabular}


Species Composition And Habitat Preference Of Rotifera In Ahansar Lake

\begin{tabular}{|cl|}
\hline 9. Genus & Cephalodella \\
\hline Species & Cephalodella auriculata Ehrenberg, 1838 \\
\hline ( D ). Family & Trichocercidae \\
\hline 10. Genus & Trichocerca \\
\hline Species & Trichocerca longiseta Schrank, 1802 \\
\hline \multicolumn{1}{c|}{ Trichocerca cylindrical Imhof, 1891 } \\
\hline & Trichocerca porcellus Gosse, 1886 \\
\hline ( E ). Family & Gastropodidae \\
\hline 11. Genus & Ascomorpha \\
\hline Species & Ascomorpha saltans Bartsch ,1870 \\
\hline ( F ). Family & Synchaetidae \\
\hline 12. Genus & Polyarthra \\
\hline & \\
\hline Species & Polyarthra vulgaris Carlin 1943 \\
\hline ORDER & FLOSCULARIACEAE \\
\hline ( G ). Family & Trochosphaeridae \\
\hline 13. Genus & Filinia \\
\hline Species & Filinia longiceta Ehrenberg 1834 \\
\hline ORDER & BDELLOIDEA \\
\hline ( H ). Family & Philodinidae \\
\hline 14. Genus & Philodina \\
\hline Species & Philodina roseola Ehrenberg 1832 \\
\hline
\end{tabular}

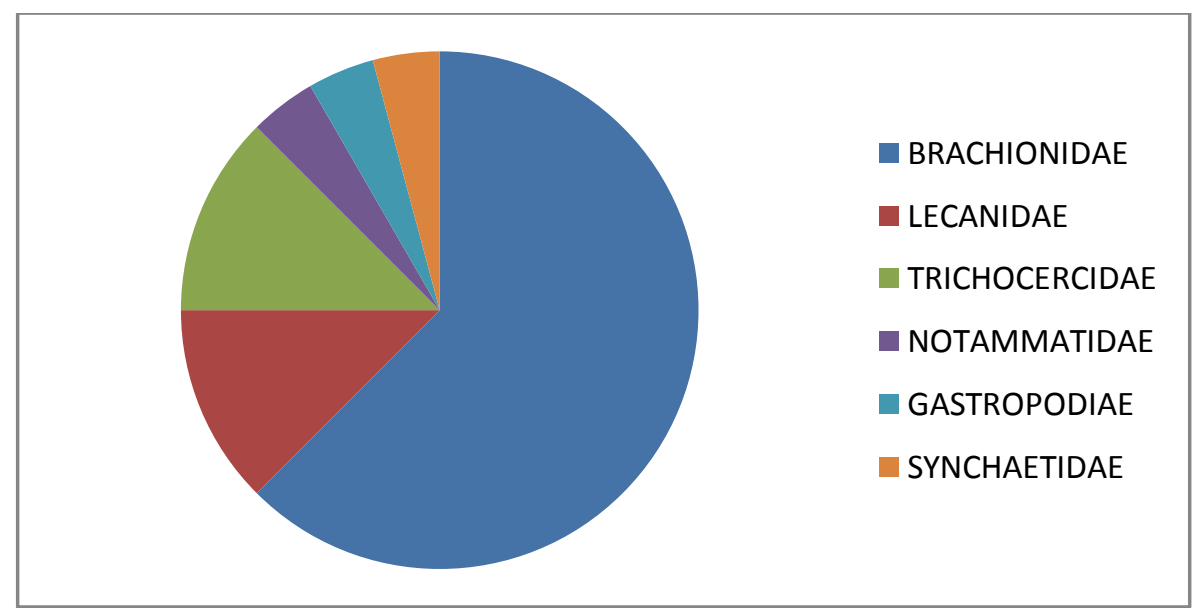

Fig 1 . BRACHIONIDAE 65\%, LECANIDAE 13\% , TRICHOCERCIDAE 13\% , NOTAMMATIDAE $1 \%$, DASTROPODIAE $1 \%$, SYNCHAETIDAE $1 \%$.

\section{Habitat Preference}

Present study showed a clear relation ship of rotifer richness and habitat heterogeneity ( Table 1 ). Rotifer distribution was non homogenous. In the present study the Shannon s index for the Rotifers sampled at two sites was found ( 2.93 and 2.07 ). These index values indicate Site 1 has a well rotifer community . 24 taxa were recorded at Site 1 in vegetated littoral zone with dense emergent, floating macrophytes, while less number of rotifer 11 taxa were recorded at Site 2 in pelagic zone. This site is not typical open water zone but only a small area of unvegetated part of the lake surrounded by sub merged macrophytes which may provide this zone with some littoral species being washed out from macrophytes . Littoral zone of a lake has more biodiversity as light is more available here which results the abundant vegetation . It causes more dissolved oxygen in water. So consumers are more in this zone. Water is relatively warmer in thelittoral zone . Light can 
penetrate up to the bottom . The present study relates diverse species of rotifers with dense vegetation which gives refuge, light, food, warmth and dissolved oxygen . Lawniczak .et .al ( 2007 ) reported most diverse species in the littoral zone and related it with heterogeneity of macrophyte dominated area . Hakanson ( 2003 ) attributed this to food availability .

Brachionus calyciflorus, Brachionus plicatalis, Keratella cochlearis, Platiyas patulus, Platiyas quadricornis , , Lepadella ovalis, Monostyla bulla , Ascomorpha saltans were common in both sampling sites .The presence of some littoral species with in the pelagic zone is often accidental due to washing out from aquatic plants and as a result of increase in trophy ( Pejler and Berzins 1993 a ) .

Among the two sites Polythra vulgaris and Filinia longiceta occurred only at Site 2 (pelagic zone). Polyarthra vulgaris was also recorded in limnetic zone of Manasbal lake (Yusuf and Farooq; 1994). Polyarthra vulgaris are common in the limnetic zone than in the littoral zone (Jose de paggi, S. 1995). Brachionus angularis, Brachionus bidentata, Brachionus quadridentata, Monostyla lunaris , Monostyla quadridentata , Keratella quadrata , Keratella haemalis , Mytilina mucronata , Notholca acuminate , Lepadella patella , Cephalodella auriculata, Trichocerca longiceta , Trichocerca cylindrica, Trichocerca porcellus , Philodina roseola were recorded only at Site 1 ( littoral zone ). According to Jyoti and Sehgal (1979) more than two species of a rotifer genus do not occur together in a water body. In the present study the presence of 5 species of Brachionus at Site 1 were recorded simultaneously .This indicates their wide distribution in water body . Brachionus was represented by 5 species . Brachionus is the index of eutrophic water (Sladeck, 1983 ) and its abundance is considered as a biological indicator of eutrophication ( Noguiro .M . G ; 2001 ). more Analyzing seasonal variation it was found that Summer peiod was characterised by highest density and lowest density in Winter at both sites(Table 2 and fig 2).

Table 1

List of rotifer indi/l recorded at two sites of Ahansar lake from December 2011-October 2012.

Site $1 \quad$ Site 2

\begin{tabular}{|l|r|}
\hline Ascomorpha saltans & 16 \\
\hline Brachionus angularis & 9 \\
\hline Brachionus bidentata & 6 \\
\hline Brachionus calyciflorus & 43 \\
\hline Brachionus plicatalis & 12 \\
\hline Brachionus quadridentata & 43 \\
\hline Keratella cochlearis & 25 \\
\hline Keratella haemalis & 4 \\
\hline Keratella quadrata & 25 \\
\hline Mytilina mucronata & 8 \\
\hline Notholca acuminata & 4 \\
\hline Platiyas patulus & 12 \\
\hline Platiyas quadricornis & 8 \\
\hline Trichotria tettractris & 8 \\
\hline Lepadella ovalis & 8 \\
\hline Lepadella patella & 4 \\
\hline Monostyla bulla & 21 \\
\hline Monostyla quadridentata & 8 \\
\hline Monostyla lunaris & 4 \\
\hline Cephalodella auriculata & 6 \\
\hline Trichocerca longiceta & 6 \\
\hline Trichocerca cylindrica & 15 \\
\hline Trichocerca porcellus & 10 \\
\hline Philodina roseola & 2.879 \\
\hline Shannon wienner index & \\
\hline
\end{tabular}




\begin{tabular}{|l|r|}
\hline Ascomorpha saltans & 4 \\
\hline Brachionus calyciflorus & 30 \\
\hline Brachionus plicatalis & 4 \\
\hline Platiyas patulus & 7 \\
\hline Platiyas quadricornis & 4 \\
\hline Lepadella ovalis & 8 \\
\hline Lepadella patella & 4 \\
\hline Monostyla bulla & 16 \\
\hline Filinia longiceta & 6 \\
\hline Polythra vulgaris & 6 \\
\hline Keratella cochlearis & 38 \\
\hline Shannon wienner index & 2.013 \\
\hline
\end{tabular}

Table 2.

\begin{tabular}{|l|r|r|r|r|}
\hline Taxa & \multicolumn{1}{l|}{ Winter } & \multicolumn{1}{l|}{ lpring } & \multicolumn{1}{l|}{ Summer } & \multicolumn{1}{l|}{ Autumn } \\
\hline Ascomorpha saltans & 0 & 4 & 12 & 0 \\
\hline Brachionus angularis & 0 & 0 & 3 & 6 \\
\hline Brachionus bidentata & 0 & 2 & 4 & 0 \\
\hline Brachionus calyciflorus & 0 & 5 & 21 & 17 \\
\hline Brachionus plicatalis & 0 & 1 & 5 & 2 \\
\hline Brachionus quadridentata & 0 & 2 & 7 & 3 \\
\hline Keratella cochlearis & 4 & 16 & 2 & 21 \\
\hline Keratella haemalis & 0 & 0 & 4 & 0 \\
\hline Keratella quadrata & 5 & 17 & 3 & 0 \\
\hline Mytilina mucronata & 0 & 0 & 8 & 0 \\
\hline Notholca acuminata & 4 & 0 & 0 & 0 \\
\hline Platiyas patulus & 0 & 3 & 9 & 0 \\
\hline Platiyas quadricornis & 0 & 0 & 5 & 3 \\
\hline Trichotria tetractris & 2 & 4 & 2 & 0 \\
\hline Lepadella ovalis & 2 & 4 & 2 & 0 \\
\hline Lepadella patella & 0 & 2 & 2 & 0 \\
\hline Monostyla bulla & 0 & 5 & 12 & 4 \\
\hline Monostyla lunaris & 0 & 0 & 4 & 0 \\
\hline Monostyla quadridentata & 2 & 2 & 4 & 0 \\
\hline Cephalodella auriculata & 0 & 2 & 4 & 0 \\
\hline Trichocerca longiceta & 0 & 0 & 6 & 0 \\
\hline Trichocerca cylindrica & 2 & 2 & 3 & 8 \\
\hline Trichocerca porcellus & 0 & 4 & 0 & 0 \\
\hline Filinia longiceta & 0 & 0 & 0 & 0 \\
\hline Polyarthra vulgaris & 0 & 0 & 0 & 0 \\
\hline Philodina roseola & 0 & 2 & 3 & 5 \\
\hline Shannon wienner index & 1.869 & 2.476 & 2.853 & 1.9 \\
\hline
\end{tabular}


Fig 2

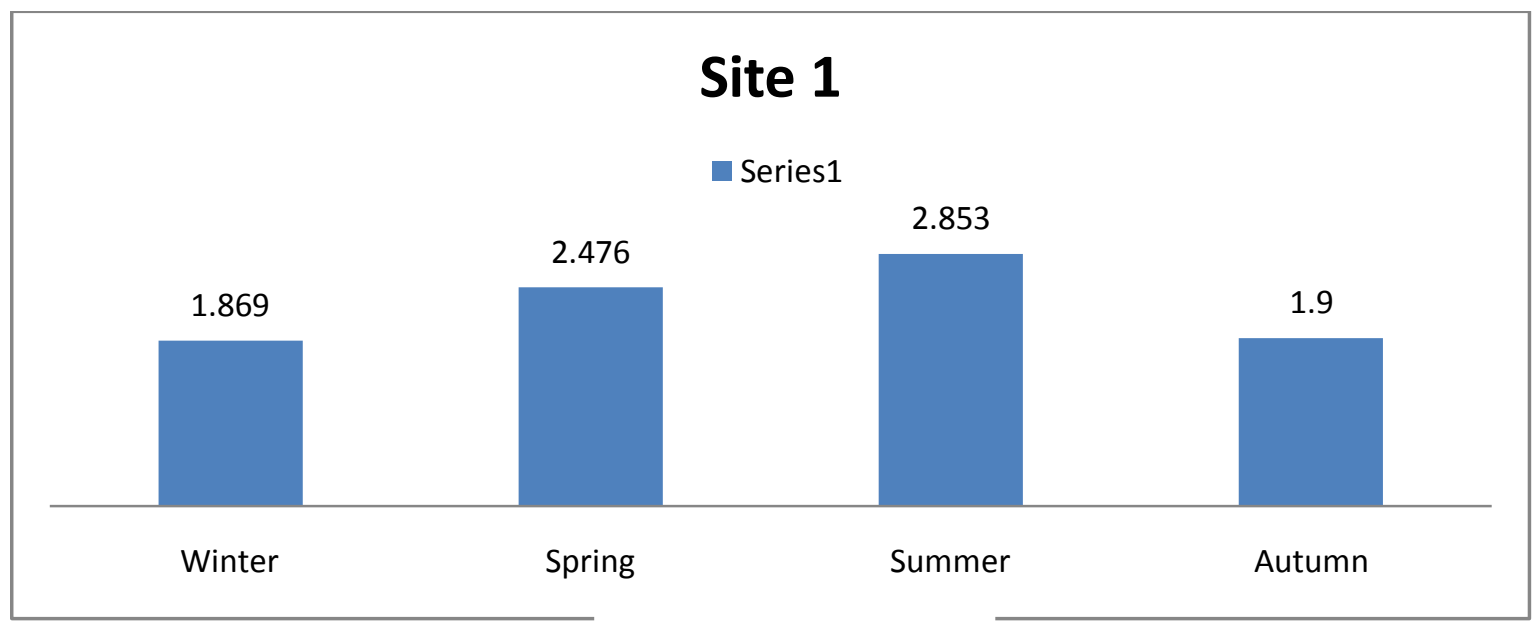

Fig 3

Table 3

\begin{tabular}{|c|c|c|c|c|}
\hline Taxa & Winter & Spring & Summer & Autumn \\
\hline Ascomorpha saltans & 0 & 0 & 4 & 0 \\
\hline $\mathrm{x}$ & 0 & 0 & 0 & 0 \\
\hline $\mathrm{x}$ & 0 & 0 & 0 & 0 \\
\hline Brachionus calyciflorus & 0 & 7 & 13 & 10 \\
\hline Brachionus plicatalis & 0 & 0 & 3 & 1 \\
\hline 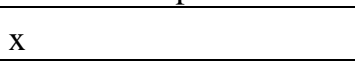 & 0 & 0 & 0 & 0 \\
\hline Keratella cochlearis & 8 & 16 & 6 & 8 \\
\hline $\mathrm{x}$ & 0 & 0 & 0 & 0 \\
\hline $\mathrm{x}$ & 0 & 0 & 0 & 0 \\
\hline $\mathrm{x}$ & 0 & 0 & 0 & 0 \\
\hline $\mathrm{x}$ & 0 & 0 & 0 & 0 \\
\hline Platiyas patulus & 0 & 0 & 4 & 3 \\
\hline Platiyas quadricornis & 0 & 0 & 4 & 0 \\
\hline $\mathrm{x}$ & 0 & 0 & 0 & 0 \\
\hline Lepadella ovalis & 0 & 0 & 2 & 6 \\
\hline Lepadella patella & 0 & 4 & 0 & 0 \\
\hline Monostyla bulla & 0 & 4 & 4 & 8 \\
\hline $\mathrm{x}$ & 0 & 0 & 0 & 0 \\
\hline $\mathrm{x}$ & 0 & 0 & 0 & 0 \\
\hline $\mathrm{x}$ & 0 & 0 & 0 & 0 \\
\hline $\mathrm{x}$ & 0 & 0 & 0 & 0 \\
\hline $\mathrm{x}$ & 0 & 0 & 0 & 0 \\
\hline $\mathrm{x}$ & 0 & 0 & 0 & 0 \\
\hline Filinia longiseta & 0 & 0 & 4 & 2 \\
\hline Polythra vulgaris & 0 & 0 & 6 & 12 \\
\hline $\mathrm{x}$ & 0 & 0 & 0 & 0 \\
\hline Shannon wienner index & 0 & 1.206 & 2.167 & 1.881 \\
\hline
\end{tabular}




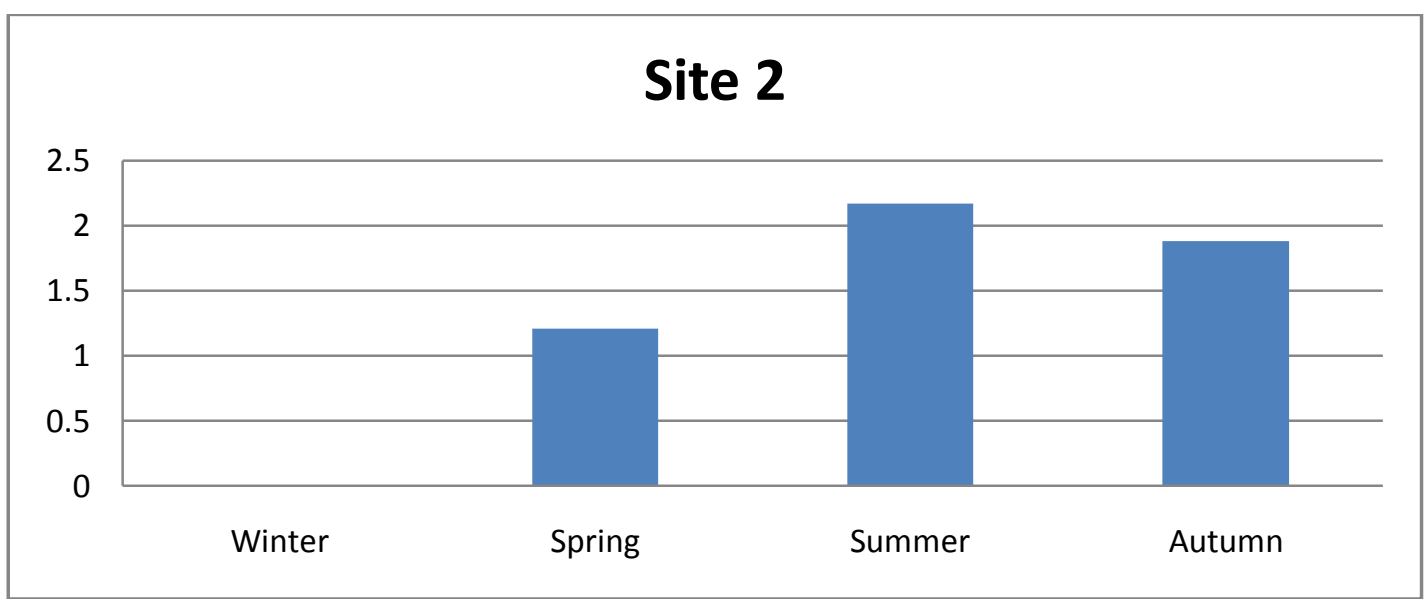

(Fig 2) Seasonal variation of rotifers at two sites in Ahansar Lake during December 2011 - October 2012

\section{Discussion}

In the present study, the majority of the recorded species were Monogonanta where as Bdelloids were represented by Philodina. The former was dominated by Order Ploima.The rotifer communities of Ahansar lake are characterised by notably high richness of Brachionidae and that of Brachionus in particular which was represented by five species. Brachionus is the index of eutrophic water ( Sladeck, 1983 ) and its abundance is considered as a biological indicator of eutrophication .

Less number of Rotifera were recorded at site 2 ( pelagic zone ). This site is not typical open water zone but only a small area of unvegetated part of the lake surrounded by submerged macrophytes which may provide this zone with some littoral species being washed out from macrophytes. According to ( Pejler and Berzins 1993 a ) the presence of some littoral species with in the pelagic zone is often accidental due to washing out from aquatic plants .

littoral zone of a lake has more biodiversity as light is more available here which results the abundant vegetation. It causes more dissolved oxygen in water. So consumers are more in this zone. Water is relatively more warmer in the littoral zone. The present study relates diverse species of Rotifers with dense vegetation which gives refuge, light, food, warmth and dissolved oxygen . Lawniczak . et .al ( 2007 ) reported most diverse species in the littoral zone and related it with heterogeneity of macrophyte dominated area. Hakanson ( 2003 ) attributed this to food availability .

Polyarthra vulgaris was recorded in pelagic zone. This species was also recorded in the limnetic zone by ( Yousuf and Farooq ; 1994 ). According to Jose de paggi , S ( 1995 ) Polyarthra vulgaris are more common in limnetic zone than in littoral zone .

To sum up it was found that the heterogeneity of the habitat is responsible for the greatest species diversity of the Rotifera community.High temperature increases the reproductive and metabolic rates resulting in abundant growth .

\section{Conclusion}

Distribution of Rotifers were influenced greatly by various factors. From the results it could be concluded that availability of safe habitat, food resources, warmth are important for the occurrence and abundance of Rotifers .

[1] APHA ; 1998 . Standard methods for examination of water and Waste water. American public health association 20th Ed , APHA ,New York

[2] De Azevedo ,F and C.C , Bonecker .2003. Community size structure of zooplanktonic assemblages in three lakes on the upper River Parans flood plain , PP - MS , Brazil . Hydrobiologia ,505 : 147 - 158

[3] Dodson, S . I ; 1992 . Predicting zooplankton species richness .Limnol . Oceanogr .37, $848-856$

[4] Edmondson,W . T ; 1959 .Fresh water Biology ( Ed : W . T . Edmond ). 2nd Edn, John Willey and sons, Inc; New York .

[5] Hakenson, L . Boulin, v. v and Ostapenia, A ; 2003. The influence of biomanipulation ( fish removal) on the structure of lake and web , case studies.

[6] Jacek Lawniczak; Kasper Swidnicki , Malgorzata Wisniewska ,Adam Bodziocl ,Natalia Kuczynskan Kippen Scientific society of naturalists : Hydrobiology section ,Faculty of Biology , Adam Mickiewicz University, Umultowska 89, 61 -614, Poznam ,Poland

[7] Nogueira .M .G ; 2001 . zooplankton composition, dominance and abundance as indicator of environmental compartmentalization in Jurumirim reservoir ( Parana Panema River ), Sao Paulo , Brazil , Hydrobiologia $455: 1$ - 18 .1

[8] Pejler. B ; 1995 .Relation to habitats in rotifers. Hydrobiologia $313-314: 267278$.

[9] Pejler . B and Berzins .B; 1993a. On the ecology of Trichocercidae (Rotifera ). Hydrobiologia 263 :55 -99 . 
[10] Pennak, R. W; 1966. Structure of zooplankton population in littoral macrophytes zone of some Colorado lakes. Trans. Am. microsc Sic. 85. $329-349$.

[11] Pennak, R.w; 1978. Fresh water invertebrates of the United States, 2nd edition.

[12] Sharma, B. K; 1998 .Rotifera . In: Faunal diversity in Indic .Eds . J .R .B. Alferd . A .K. Das and A .K. Sanyal . Envis center, Zoological survey of India. PP .57 -70

[13] Shannon .C .E and Weaver.W .1949 .The mathematical theory of communication $19.27 .83-88.104-107$. The university of Illinois press. Urbana 11.

[14] Shiel, R . J; 1995 . A guide to the identification of Rotifers, Cladocerans and Copopods from Australian waters .Presented at the Taxonomy workshop held at the Murray -Darling Fresh water Research centre , Albury ,8 -10

[15] Sladeck, V; 1983. Rotifers as indicators of water quality, Hydrobiologia, 100, $169-220$

[16] Yousuf .A .R and Farooq. M; 1994. Vertical distribution of Rotifera in a warm Monomictic Lake of Kashmir. J. Fresh water Biol .6 (2) : $143-149$ 